\title{
STEROIDAL GLYCOSIDES FROM THE FLOWERS OF Allium leucanthum
}

\author{
Lasha Mskhiladze, ${ }^{1}$ David Chincharadze, ${ }^{1}$ Vakhtang Mshvildadze, ${ }^{2}$ André Pichette, ${ }^{2}$ Michel Frederich, ${ }^{3}$ Evelyne \\ Ollivier, ${ }^{4}$ and Riad Elias ${ }^{4}$ \\ ${ }^{1}$ Department of Pharmacognosy and Botany, Faculty of Pharmacy, Tbilisi State Medical University, 33, Vazha PshavelaAve., 0177, Tbilisi, \\ Georgia \\ ${ }^{2}$ Laboratoire LASEVE, Département des Sciences Fondamentales, Université du Quebec à Chicoutimi, 555 Boul. Université, Chicoutimi, \\ Quebec, Canada, G7H2BI \\ ${ }^{3}$ Laboratoire de Pharmacognosie, Département de Pharmacie, Centre Interfacultaire de Recherche du Medicament-CIRM, University of \\ Liège, CHU-B36, B-4000 Liège, Belgium \\ ${ }^{4}$ Laboratoire de Pharmacognosie-Ethnopharmacologie, UMR-MD3, AMU Faculté de Pharmacie, 27 Boul. JeanMoulin, CS30064,13385 \\ Marseille, cedex 5, France.
}

\begin{abstract}
Furostanol and spirostanol glycosides 1 and $\mathbf{2}$ were isolated from the flowers of Allium leucanthum, a Caucasian endemic species that grows in Georgia. The structures were established on the base of chemical evidence and spectral analyses $\left({ }^{1} \mathrm{H},{ }^{\mathrm{B}} \mathrm{CNMR},{ }^{1} \mathrm{H}-{ }^{1} \mathrm{H}\right.$ COSY,${ }^{1} \mathrm{H}-{ }^{\mathrm{B}} \mathrm{C}$ COSY, HMBC, and HR-MS) data. Compound 1 (leucofuranoside A) was reported for the first time and was identified as 26-O- $\beta$-D-glucopyranosyl- $(25 \mathrm{R})-5 \alpha-$ furostane-3 $\beta, 6 \beta$-diol-3-O- $\beta$-D-glucopyranosyl- $(1 \rightarrow 2)-O-\beta$-D-xylopyranosyl- $(1 \rightarrow 3)-O-\beta$-D-glucopyranosyl$(1 \rightarrow 4)-\beta$-D-galactopyranoside. Compound 2 was identified as $(25 \mathrm{R})-5 \alpha$-spirostane-3 $\beta, 6 \beta-$ diol-3-O- $\beta$-Dglucopyranosyl- $(1 \rightarrow 2)-\beta$-D-glucopyranosyl- $(1 \rightarrow 4)-\beta$-D-galactopyranoside and described for the first time in the genus Allium.
\end{abstract}

Keywords : Allium leucathum; Alliaceae ; spirostanol glycoside ; furostanol glycoside ; leucofuranoside A.

Saponins are an important family of glycosylated secondary metabolites that are widely distributed in the plant kingdom [1]. Besides food industrial and pharmaceutical applications, saponins are known to be the main constituents of several herbal drugs and folk medicines used worldwide [2]. Their biological activities are linked to the structure of both the aglycone and the sugar moieties. The incredibly wide chemical diversity of saponins has led to a sustained and renewed interest in these compounds.

The genus Allium includes up to 800 species of the world's flora. Among them, some 70 grow in the Caucasian region and 35 species are described in Georgia [3]. Allium leucanthum K. Koch (Alliaceae), called "whiteflower onion" in Georgia, is a Caucasian endemic species and, along with other Allium species, is widely used in Georgian traditional medicine as an antiseptic and antibacterial remedy. Various secondary metabolites have been identified in the genus Allium [4, 5]. Among them, steroidal saponins have been investigated for their antibacterial, antileishmanial, antifungal [6-9], cytotoxic [10, 11], and antioxidant activities [12]. Furthermore, steroidal saponins isolated from different species of Allium have shown significant cytotoxic activity [13-16],

This paper describes the isolation of spirostanol and furostanol glycosides from the flowers of Allium leucanthum that grow in Georgia and the structural determination of two these compounds by ${ }^{1} \mathrm{H},{ }^{13} \mathrm{C}$ nuclear magnetic resonance (NMR), ${ }^{1} \mathrm{H}-{ }^{1} \mathrm{H}$ correlation spectroscopy (COSY), ${ }^{1} \mathrm{H}-{ }^{13} \mathrm{C}$ COSY, heteronuclear multiple bond correlation (HMBC), and high-resolution mass spectroscopy (HR-MS), and the results of hydrolytic cleavage.

Dried and powdered flowers of Allium leucanthum (500 g) were extracted twice with hot $\mathrm{MeOH}-\mathrm{H}_{2} \mathrm{O}(8: 2, \mathrm{v} / \mathrm{v})$. After removal of solvent, the extract was suspended in water and then extracted with $n$-BuOH The $n$ - $\mathrm{BuOH}$ extract was chromatographed over Diaion $\mathrm{HP}-20$, using $\mathrm{MeOH}-\mathrm{H}_{2} \mathrm{O}$ as the eluent in gradient conditions and EtOAc. The spirostanol fraction was collected in $\mathrm{MeOH}-\mathrm{H}_{2} \mathrm{O}(7: 3, \mathrm{v} / \mathrm{v})$, and the furostanol fraction in $\mathrm{MeOH}-$ $\mathrm{H}_{2} \mathrm{O}(5: 5, \mathrm{v} / \mathrm{v})$. The spirostanol and furostanol fractions were subjected to column chromatography (CC) on silica 
gel to give compounds 1 and 2 .

TABLE 1. ${ }^{1} \mathrm{H}(400 \mathrm{MHz})$ and ${ }^{13} \mathrm{C}(100 \mathrm{MHz}) \mathrm{NMR}$ Data of Compound 1 (pyridine- $\left.\mathrm{d}_{5}-\mathrm{D}_{2} \mathrm{O}, 10: 1, \delta, \mathrm{ppm}\right)$

\begin{tabular}{|c|c|c|c|c|c|}
\hline C atom & $\delta_{\mathrm{C}}(\mathrm{DEPT})$ & $\delta_{\mathrm{H}}$ & C atom & $\delta_{\mathrm{C}}(\mathrm{DEPT})$ & $\delta_{\mathrm{H}}$ \\
\hline Aglycone & & & Glc-A & & \\
\hline 1 & $38.8\left(\mathrm{CH}_{2}\right)$ & $1.53,0.89$ & 1 & $104.4(\mathrm{CH})$ & 5.15 \\
\hline 2 & $29.9\left(\mathrm{CH}_{2}\right)$ & $2.13,1.77$ & 2 & $80.8(\mathrm{CH})$ & 4.32 \\
\hline 3 & $78.4(\mathrm{CH})$ & 4.08 & 3 & $86.9(\mathrm{CH})$ & 4.12 \\
\hline 4 & $32.4\left(\mathrm{CH}_{2}\right)$ & 2.272 .13 & 4 & $69.9(\mathrm{CH})$ & 3.77 \\
\hline 5 & $47.8(\mathrm{CH})$ & 1.07 & 5 & $77.1(\mathrm{CH})$ & 3.85 \\
\hline 6 & $70.8(\mathrm{CH})$ & 4.00 & 6 & $62.4\left(\mathrm{CH}_{2}\right)$ & $4.50,4.06$ \\
\hline 7 & $40.1\left(\mathrm{CH}_{2}\right)$ & $1.76,1.14$ & Glc-B & & \\
\hline 8 & $30.4(\mathrm{CH})$ & 2.17 & 1 & $104.2(\mathrm{CH})$ & 5.58 \\
\hline 9 & $54.5(\mathrm{CH})$ & 0.63 & 2 & $75.6(\mathrm{CH})$ & 4.06 \\
\hline 10 & $35.9(\mathrm{C})$ & - & 3 & $77.4(\mathrm{CH})$ & 4.21 \\
\hline 11 & $20.9\left(\mathrm{CH}_{2}\right)$ & 1.42 & 4 & $70.8(\mathrm{CH})$ & 4.20 \\
\hline 12 & $40.4\left(\mathrm{CH}_{2}\right)$ & $2.06,1.14$ & 5 & $78.2(\mathrm{CH})$ & 3.96 \\
\hline 13 & $41.2(\mathrm{C})$ & - & 6 & $62.0\left(\mathrm{CH}_{2}\right)$ & $4.50,4.39$ \\
\hline 14 & $56.1(\mathrm{CH})$ & 1.11 & Xyl & & \\
\hline 15 & $32.3\left(\mathrm{CH}_{2}\right)$ & $2.10,1.50$ & 1 & $104.6(\mathrm{CH})$ & 5.19 \\
\hline 16 & $81.2(\mathrm{CH})$ & 4.99 & 2 & $74.7(\mathrm{CH})$ & 3.95 \\
\hline 17 & $63.4(\mathrm{CH})$ & 2.01 & 3 & $77.9(\mathrm{CH})$ & 4.13 \\
\hline 18 & $16.7(\mathrm{Me})$ & 0.89 & 4 & $70.4(\mathrm{CH})$ & 4.13 \\
\hline 19 & $15.9(\mathrm{Me})$ & 1.21 & 5 & $66.9\left(\mathrm{CH}_{2}\right)$ & $4.26,3.71$ \\
\hline 20 & $40.4(\mathrm{CH})$ & 2.25 & Glc-C & & \\
\hline 21 & $16.2(\mathrm{Me})$ & 1.36 & 1 & $104.4(\mathrm{CH})$ & 4.81 \\
\hline 22 & $110.9(\mathrm{C})$ & - & 2 & $74.8(\mathrm{CH})$ & 4.03 \\
\hline 23 & $36.7\left(\mathrm{CH}_{2}\right)$ & 2.07 & 3 & $77.9(\mathrm{CH})$ & 4.29 \\
\hline 24 & $28.1\left(\mathrm{CH}_{2}\right)$ & $2.04,1.65$ & 4 & $71.3(\mathrm{CH})$ & 4.15 \\
\hline 25 & $34.1(\mathrm{CH})$ & 1.96 & 5 & $78.0(\mathrm{CH})$ & 3.97 \\
\hline 26 & $75.3\left(\mathrm{CH}_{2}\right)$ & $3.98,3.67$ & 6 & $62.4\left(\mathrm{CH}_{2}\right)$ & $4.52,4.31$ \\
\hline 27 & $17.3(\mathrm{Me})$ & 1.03 & & & \\
\hline \multicolumn{6}{|l|}{ Gal } \\
\hline 1 & $102.1(\mathrm{CH})$ & 5.01 & & & \\
\hline 2 & $72.7(\mathrm{CH})$ & 4.44 & & & \\
\hline 3 & $75.1(\mathrm{CH})$ & 4.20 & & & \\
\hline 4 & $79.7(\mathrm{CH})$ & 4.61 & & & \\
\hline 5 & $75.1(\mathrm{CH})$ & 4.09 & & & \\
\hline 6 & $60.7\left(\mathrm{CH}_{2}\right)$ & $4.63,4.28$ & & & \\
\hline
\end{tabular}

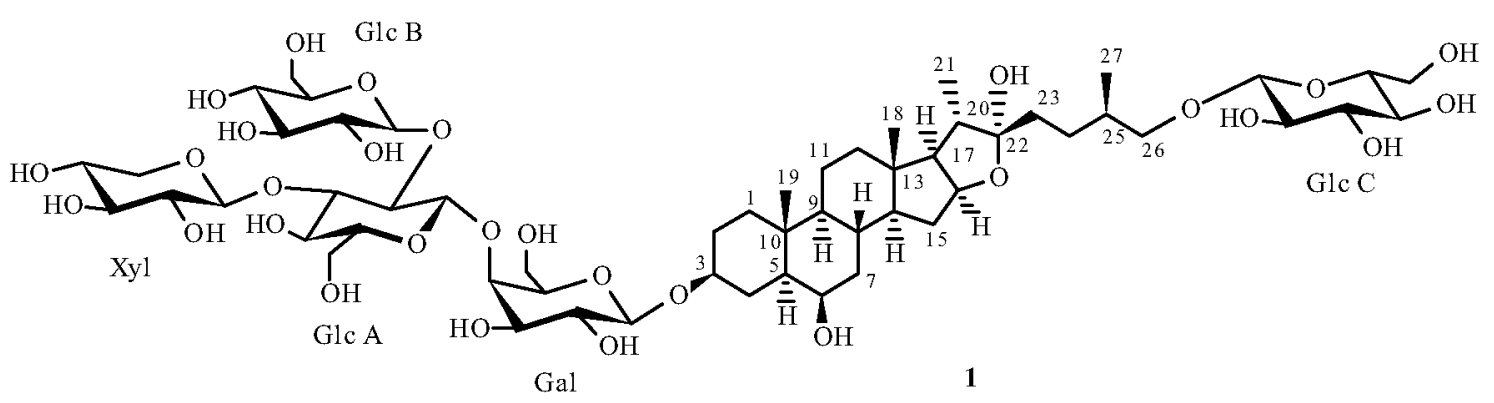

Compound 1 was obtained as an amorphous solid: $[\alpha]_{\mathrm{D}}{ }^{24}-45.3^{\circ}$ (c $\left.0.35, \mathrm{MeOH}\right)$. High-resolution (HR)electrospray ionization (ESI)-time of flight (TOF)-MS of 1 showed an $[\mathrm{M}+\mathrm{Na}]^{+}$peak at $\mathrm{m} / z 1253.5773$ corresponding to the empirical molecular formula $\mathrm{C}_{56} \mathrm{H}_{\mathrm{g} 4} \mathrm{O}_{29}$. The ${ }^{1} \mathrm{H}$ NMR spectrum of 1 (Table 1) showed characteristic proton signals due to two tertiary methyls at $\delta 0.89(3 \mathrm{H}, \mathrm{s})$ and $1.21(3 \mathrm{H}, \mathrm{s})$, two secondary methyls at $\delta 1.03(3 \mathrm{H}, \mathrm{d}, \mathrm{J}=6.5 \mathrm{~Hz})$ and $1.36(3 \mathrm{H}, \mathrm{d}, \mathrm{J}=6.8 \mathrm{~Hz})$, and five anomeric protons at $\delta 5.01(1 \mathrm{H}, \mathrm{d}, \mathrm{J}=$ $7.6 \mathrm{~Hz}), 5.15(1 \mathrm{H}, \mathrm{d}, \mathrm{J}=7.8 \mathrm{~Hz}), 5.58(1 \mathrm{H}, \mathrm{d}, \mathrm{J}=7.9 \mathrm{~Hz}), 5.19(1 \mathrm{H}, \mathrm{d}, \mathrm{J}=7.8 \mathrm{~Hz})$, and $4.81(1 \mathrm{H}, \mathrm{d}, \mathrm{J}=7.8 \mathrm{~Hz})$. The ${ }^{13} \mathrm{C}$ NMR spectrum showed 56 peaks: 29 for the sugar moieties, including five anomeric carbons at $\delta 102.1$, 104.4, 104.2, 104.6, and 104.4, and 27 for the aglycone part (Table 1). The ${ }^{1} \mathrm{H}$ NMR data, an acetylic carbon 
signal at $\delta_{\mathrm{C}} 110.9$ in the ${ }^{13} \mathrm{C}$ NMR spectrum, and a positive color reaction in Ehrlich's test indicated 1 to be a furostanol saponin. Enzymatic hydrolysis of 1 produced a spirostanol saponin, identified by comparison with reference samples as $(25 R)-5 \alpha$-spirostane- $3 \beta, 6 \beta$-diol-3-O- $\beta$-D-glucopyranosyl- $(1 \rightarrow 2)$ - $[\beta$-D-xylopyranosyl$(1 \rightarrow 3)]-\beta$-D-glucopyranosyl- $(1 \rightarrow 4)-\beta$-D-galactopyranoside [4] and glucose. Chiral GC-FID analyses of the monosaccharides obtained after acid hydrolysis of 1 confirmed the D conformation of galactose, glucose, and xylose. As is usual with naturally occurring furostanol glycosides, one glucosyl group was shown to be linked to the C-26 hydroxyl group of the aglycone by an HMBC correlation of the anomeric proton at $\delta 4.81(3 \mathrm{H}, \mathrm{d}, \mathrm{J}=$ $7.8 \mathrm{~Hz})$ with $\mathrm{C}-26$ of the aglycone at $\delta_{\mathrm{C}} 75.3$. Thus, 1 was identified as $26-O-\beta$-D-glucopyranosyl- $(25 R)-5 \alpha-$ furostane-3 $\beta,-6 \beta$-diol-3- $O$ - $\beta$-D-glucopyranosyl- $(1 \rightarrow 2)-O-\beta$-D-xylopyranosy1-( $1 \rightarrow 3)-O-\beta$-D-glucopyranosyl$(1 \rightarrow 4)-\beta$-D-galactopyranoside and was named leucofuroside $\mathrm{A}$.

Compound 2 was isolated as an amorphous solid: $[\alpha]_{\mathrm{D}}{ }^{24}-34.0^{\circ}(c 0.10, \mathrm{MeOH})$. HR-ESI-TOF-MS of 2 showed a pseudomolecular ion peak at $m / z 941.4716[\mathrm{M}+\mathrm{Na}]^{+}$, corresponding to the empirical molecular formula $\mathrm{C}_{45} \mathrm{H}_{74} \mathrm{O}_{19}$, which was also deduced by analysis of its ${ }^{13} \mathrm{C}$ NMR and distortionless enhancement by polarization transfer (DEPT) spectral data. The ${ }^{1} \mathrm{H}$ NMR spectrum of 2 showed characteristic proton signals due to two tertiary methyls at $\delta 0.82(3 \mathrm{H}, \mathrm{s})$ and $1.05(3 \mathrm{H}, \mathrm{s})$, two secondary methyls at $\delta 0.79(3 \mathrm{H}, \mathrm{d}, \mathrm{J}=6.4 \mathrm{~Hz})$ and 0.95 $(3 \mathrm{H}, \mathrm{d}, \mathrm{J}=7.0 \mathrm{~Hz})$, and three anomeric protons at $\delta 4.39(1 \mathrm{H}, \mathrm{d}, \mathrm{J}=7.2 \mathrm{~Hz}), 4.53(1 \mathrm{H}, \mathrm{d}, \mathrm{J}=7.2 \mathrm{~Hz})$, and 4.66 $(1 \mathrm{H}, \mathrm{d}, \mathrm{J}=7.8 \mathrm{~Hz})$. The ${ }^{13} \mathrm{C}$ NMR spectrum showed 45 peaks: 18 for the sugar moieties, including three anomeric carbons at $\delta 102.5,104.8$, and 106.2, and 27 for the aglycone part. Acid hydrolysis of 2 with $1 \mathrm{M} \mathrm{HC1}$ in dioxane- $\mathrm{H}_{2} \mathrm{O}(1: 1, \mathrm{v} / \mathrm{v})$ produced steroidal sapogenin, glucose, and galactose. Chiral gas chromatography flame ionization detector (GC-FID) analyses of the monosaccharides confirmed their D-configuration. The physical and spectral data allowed the identification of the sapogenin as $(25 R)-5 \alpha$-spirostane-3 $\beta,-6 \beta$-diol $(\beta$ chlorogenin) [17], suggesting 2 to be a $\beta$-chlorogenin triglycoside. ${ }^{1} \mathrm{H}-{ }^{1} \mathrm{H}$ shift COSY allowed the sequential assignments from $\mathrm{H}-1$ to $\mathrm{H}_{2}-6$ of each monosaccharide, including identification of their multiple patterns and coupling constants. These sugar linkages were confirmed by long-range correlations on the HMB spectrum. The ${ }^{1} \mathrm{H}$ and ${ }^{13} \mathrm{C}$ NMR signals indicated the presence of a terminal $\beta$-D-glucopyranosyl unit $(\mathrm{Glc} \mathrm{B})\left[\delta_{\mathrm{H}} 4.66(\mathrm{~d}, \mathrm{~J}\right.$ $\left.=7.8 \mathrm{~Hz}) ; \delta_{\mathrm{C}} 106.2,76.3,77.5,70.7,78.7,61.9\right]$, a C-2 substituted $\beta$-D-glucopyranosyl unit $(\mathrm{Glc} \mathrm{A})\left[\delta_{\mathrm{H}} 4.53(\mathrm{~d}\right.$, $\left.\mathrm{J}=7.2 \mathrm{~Hz}) ; \delta_{\mathrm{C}} 104.8,84.9,78.1,71.7,77.8,63.2\right]$, and a C-4 substituted $\beta$-D-galactopyranosyl unit $(\mathrm{Gal})\left[\delta_{\mathrm{H}}\right.$ $\left.4.39(\mathrm{~d}, \mathrm{~J}=7.2 \mathrm{~Hz}) ; \delta_{\mathrm{C}} 102.5,73.2,75.1,80.5,75.6,60.8\right]$. In the HMBC spectrum, correlations were observed from $\delta 4.66(\mathrm{H}-1$ of Glc B) to $\delta 84.9$ (C-2 of Glc A), $\delta 4.53$ (H-1 of Glc A) to $\delta 80.5$ (C-4 of Gal), and $\delta 4.39$ (H1 of Gal) to 79.8 (C-3 of the aglycone). Thus, compound 2 was identified as $(25 R)-5 \alpha$-spirostane-3 $\beta, 6 \beta$-diol- $O-\beta$ D-glucopyranosyl- $(1 \rightarrow 2)-O-\beta$-D-glucopyranosyl- $(1 \rightarrow 4)-\beta$-D-galactopyranoside, recently isolated and characterized by Akihito et al. as compound 2 [18]. The mentioned compound was described for the first time in the genus Allium.

\section{EXPERIMENTAL}

General. Spectra were recorded on a Braker DRX-500 and a Braker Avance 400 instrument. ${ }^{1} \mathrm{H}$ and ${ }^{13} \mathrm{C}$ NMR chemical shifts in ppm were referenced with the residual solvent (CD3OD) signals $\left(\delta_{\mathrm{H}} 3.31\right.$ and $\left.\delta_{\mathrm{C}} 49.0\right)$ or with TMS as internal standard (for pyridine- $\mathrm{d}_{5}-\mathrm{H}_{2} \mathrm{O}$ ). High-resolution electrospray ionization mass spectrometry was conducted in the positive mode on an Applied Biosystems/MDS Sciex QSTAR XL QqTOF MS system. The flowers were dried by microwave irradiation oven $\operatorname{Pr} \mathrm{KS}-22 \mathrm{E}, 850 \mathrm{~W}, 2450 \mathrm{MHz}$. GC-FID analysis was performed on an Agilent 7890A series equipped with an InertCap Chiramix column $(30 \mathrm{~m} \times 0.25 \mathrm{~mm} \times 0.25$ $\mu \mathrm{m})$. The temperature program was $120^{\circ} \mathrm{C}$ for $1 \mathrm{~min}$, followed by a rise of $4^{\circ} \mathrm{C} / \mathrm{min}$ to $180^{\circ} \mathrm{C}$, which was maintained for $120 \mathrm{~min}$. Optical rotation $[\alpha]_{\mathrm{D}}{ }^{25}$ was measured on an Autopol IV polarimeter. For CC, silica gel 60 (40-63 $\mu \mathrm{m}$, Merck) and Diaion HP20 resin (Mitsubishi) were used. Thin-layer chromatography (TLC) analysis of saponins was performed on silica gel 60 F254 plates (Merck) and eluted with $\mathrm{CH}_{2} \mathrm{Cl}_{2}-\mathrm{MeOH}-\mathrm{H}_{2} \mathrm{O}$ $(26: 14: 3 \mathrm{v} / \mathrm{v} / \mathrm{v})$. Spots were detected by spraying the plates with vanillin-sulfuric acid (in EtOH) reagent, followed by heating at $110^{\circ} \mathrm{C}$ (spirostanols were colored yellow, furostanols dark green, and they gave a positive color reaction in Ehrlich's test).

Plant Material. The flowers of Allium leucanthum K. Koch were collected in the Dmanisi region of Georgia (June 2005) and identified by Prof. Jumber Kuchukhidze. A voucher specimen is kept in the Department of Pharmacognosy and Botany Faculty of Pharmacy, Tbilisi State Medical University, Tbilisi, Georgia (flowers No. AL 0605).

Extraction and Isolation. Dried and powdered flowers of Allium leucanthum (500 g) were extracted twice with hot $\mathrm{MeOH}-\mathrm{H}_{2} \mathrm{O}(8: 2, \mathrm{v} / \mathrm{v}, 5 \mathrm{~L})$. After evaporation of the solvent, the residue $(79 \mathrm{~g})$ was suspended in water and the saponins were extracted with $n$ - $\mathrm{BuOH}$ The $n$ - $\mathrm{BuOH}$ extract (32 g) was chromatographed over Diaion HP-20, using $\mathrm{MeOH}-\mathrm{H}_{2} \mathrm{O}$ as eluent in gradient conditions $(0 \rightarrow 100 \%)$ and EtOAc. The spirostanol fraction $(14.5 \mathrm{~g})$ was 
collected in $\mathrm{MeOH}-\mathrm{H}_{2} \mathrm{O}(7: 3, \mathrm{v} / \mathrm{v})$, and the furostanol fraction (5.9 g) in $\mathrm{MeOH}-\mathrm{H}_{2} \mathrm{O}(5: 5, \mathrm{v} / \mathrm{v})$. The furostanol saponins were subjected to $\mathrm{CC}$ on silica gel and eluted with $\mathrm{CH}_{2} \mathrm{Cl}_{2}-\mathrm{MeOH}-\mathrm{H}_{2} \mathrm{O}(40: 12: 2$, v/v/v) to give compound 1 (32 mg). The spirostanol saponins were subjected to $\mathrm{CC}$ on silica gel and eluted with $\mathrm{CH}_{2} \mathrm{Cl}_{2}$ $\mathrm{MeOH}-\mathrm{H}_{2} \mathrm{O}(45: 14: 2, \mathrm{v} / \mathrm{v} / \mathrm{v})$ to give compound 2 (25 mg).

Compound 1. Amorphous solid, $[\alpha]_{\mathrm{D}}{ }^{24}-45.3^{\circ}$ (c 0.35, MeOH). HR-ESI-TOS-MS $\left[\mathrm{m} / \mathrm{z} 1230.588,[\mathrm{M}+\mathrm{H}]^{+}\right.$, calcd for $\left.\mathrm{C}_{56} \mathrm{H}_{94} \mathrm{O}_{29} \mathrm{Na}, 1253.577\right]$. ${ }^{1} \mathrm{H}$ NMR (400 MHz) and ${ }^{13} \mathrm{C}$ NMR (100 MHz) spectroscopic data are shown in Table 1.

Enzymatic Hydrolysis. A solution of 1 (10 mg) was treated with $\beta$-D-glycosidase (EC, Sigma, USA) (10 mg) in $\mathrm{AcOH}-\mathrm{AcONa}$ buffer $(\mathrm{pH} 5 ; 10 \mathrm{~mL})$ at room temperature for $12 \mathrm{~h}$ The reaction mixture was chromatographed on Diaion HP-20 eluted with $\mathrm{Me}_{2} \mathrm{CO}-\mathrm{EtOH}(3: 2, \mathrm{v} / \mathrm{v})$ and on silica gel eluted with $\mathrm{CH}_{2} \mathrm{Cl}_{2}-\mathrm{MeOH}-\mathrm{H}_{2} \mathrm{O}(45: 14: 2$, $\mathrm{v} / \mathrm{v} / \mathrm{v})$ to give $(25 R)$-5 $\alpha$-spirostane-3 $\beta,-6 \beta$-diol-3- $O$ - $\beta$-D-glucopyranosyl-( $1 \rightarrow 2)-O$ - $\beta$-D-xylopyranosyl- $(1 \rightarrow 3)-O$ $\beta$-D-glucopyranosyl- $(1 \rightarrow 4)$ - $\beta$-D-galactopyranoside $(6 \mathrm{mg})$ and a sugar fraction $(2 \mathrm{mg})$. The sugar fraction was analyzed on silica gel TLC by comparison with standard sugars in a $\mathrm{CH}_{2} \mathrm{Cl}_{2}-\mathrm{MeOH}-\mathrm{H}_{2} \mathrm{O}(50: 25: 5$, v/v/v) solvent system and further developed using an orthophosphoric acid solution of 5\% naphthoresorsinol in EtOH, followed by heating at $110^{\circ} \mathrm{C}$ to give glucose.

Acid Hydrolysis. A solution of $1\left(10 \mathrm{mg}\right.$ ) in $1 \mathrm{M} \mathrm{HC1}$ (dioxane- $\mathrm{H}_{2} \mathrm{O}, 1: 1$, v/v; $3 \mathrm{~mL}$ ) was heated at $100^{\circ} \mathrm{C}$ for 2 $\mathrm{h}$ under an $\mathrm{Ar}$ atmosphere. The reaction mixture was neutralized with $\mathrm{N}, \mathrm{N}$-dioctylmethylamine $\left(10 \%\right.$ in $\left.\mathrm{CHCl}_{3}\right)$ and was chromatographed on silica gel eluted with $\mathrm{CHCl}_{3}-\mathrm{MeOH}(9: 1, \mathrm{v} / \mathrm{v})$ to give $\beta$-chlorogenin $(3.3 \mathrm{mg})$ and a sugar fraction $(5.8 \mathrm{mg})$. The sugar fraction was analyzed by silica gel TLC and comparison with standard sugars in a $\mathrm{CH}_{2} \mathrm{Cl}_{2}-\mathrm{MeOH}-\mathrm{H}_{2} \mathrm{O}(50: 25: 5, \mathrm{v} / \mathrm{v} / \mathrm{v})$ solvent system; the monosaccharides were identified by TLC in a $\mathrm{CH}_{2} \mathrm{Cl}_{2}-\mathrm{CH}_{3} \mathrm{OH}-\mathrm{H}_{2} \mathrm{O}(50: 25: 5, \mathrm{v} / \mathrm{v} / \mathrm{v})$ solvent system and further developed using an orthophosphoric acid solution of $5 \%$ naphthoresorsinol in $\mathrm{EtOH}$, followed by heating at $110^{\circ} \mathrm{C}$ to give galactose, glucose, and xylose.

Determination of Stereochemistry of Monosaccharide. The aqueous phase (after acid hydrolysis) was evaporated and dried, and the residue containing monosaccharides was acetylated with acetic anhydride (1 mL) in pyridine $(1 \mathrm{~mL})$ for $24 \mathrm{~h}$. The monosaccharide acetates were extracted with EtOAc, and the organic fraction was treated with water, followed by a saturated solution of $\mathrm{NaHCO}_{3}$. The sample obtained was analyzed by GCFID on a chiral column for comparison with authentic samples of monosaccharide acetates. The retention indices of monosaccharide acetates were compared with those of authentic samples. D-Galactose, D-glucose, and Dxylose were identified for compound $\mathbf{1 .}$

\title{
ACKNOWLEDGMENT
}

The authors are grateful for the support of the French Embassy in Georgia. We thank Prof. Jumber Kuchukhidze for identification of Allium leucanthum K. Koch, and Gilbert Boudon for his technical support. This research was partially supported by the program Shota Rustaveli National Science Foundation "Research Grants for Young Scientists 2013" (Grant Agreement Nr. YS/1/8-404/13).

\section{REFERENCES}

1. K. A. Hostettmann and A. Martson, Saponins, Cambridge University Press, Cambridge, 2005, pp. 76-96.

2. S. G. Sparg, M. E. Light, and J. Staden, J. Ethnopharmacol., 94, 219 (2004).

3. R. Gagnidze, Vascular Plants of Georgia: a Nomenclatural Checklist, N. Ketskhoveli (ed.), Institute of Botany, Republic of Georgia, Tbilisi, 2005, pp. 118-119.

\author{
4. A. Carotenuto, E. Fattorusso, V. Lanzotti, and S. Magno, Phytochemistry, 51, 1082 (1999). \\ 5. V. Lanzotti, J. Chromatogr. A, 1112, 3 (2006).
}

6. M. Amin and B. P. Kapadnis, Indian J. Exp. Biol., 43, 751 (2005).

7. E. Barile, G. Bonanomi, V. Antignani, B. Zolfaghari, S. E. Sajjadi, F. Scala, and V. Lanzotti, Phytochemistry, 68, 596 (2007).

8. K. Kyu Hang, Curr. Opinion Biotechnol., 23, 142 (2012).

9. L. Mskhiladze, J. Kutchukhidze, D. Chincharadze, F. Delmas, R. Elias, and A. Favel, Georg. Med. News, 154, 39 (2008). 
Published in: Chemistry of Natural Compounds (2015), vol. 51, iss. 5, pp. 900-904. Status: Postprint (Author's version)

10. E. Fattorusso, V. Lanzotti, O. Taglialatela-Scafati, M. Di Rosa, and A. Ianaro, J. Agric. Food Chem., 48, 3455 (2000).

11. L. Mskhiladze, J. Legault, S. Lavoie, V. Mshvildadze, J. Kuchukhidze, R. Elias, and A. Pichette, Molecules, 13, 2925 (2008).

12. D. Stajner, N. Milic-Demarino, J. Canadanovic-Brunet, M. Stajner, and B. M. Popovic, Fitoterapia, 77, 268 (2006).

13. K. Geum-Soog, K. Hyun-Tae, S. Jae-Duck, O. Sei-Ryang, L. Chong-Ock, B. Jin-Ki, S. Nak-Sul, and S. Kyung-Sik, J. Nat. Prod., 68, 766 (2005).

14. J. Jian-Ming, Z. Ying-Jun, L. Hai-Zhou, and Y. Chong-Ren, J. Nat. Prod., 67, 1992 (2004).

15. G. Papiya, E. Shila, T. Gayatri, M. Smita, and R. Joseph, Leukemia Res., 30, 459 (2006).

16. Y. Qing-Xiong and Y. Chong-Ren, Chem. Biodiv., 3, 1349 (2006).

17. L. Mskhiladze, D. Chincharadze, L. Eristavi, and J. Kuchukhidze, Georgia Chem. J., 7, 73 (2007).

18. Y. Akihito and M. Yoshihiro, Chem. Pharm. Bull., 55, 145 (2007). 